にWCになってゆく。

こてで, 金属カルシウムが応系外仙去ることは，

WC 䒼純度に製造することが可能となる上注重要な点 である、金属カルシウムは，その蒸気圧が $1,200^{\circ} \mathrm{C} て ゙$ 約 $100 \mathrm{mmHg}, 1,350^{\circ} \mathrm{C}$ で約 $300 \mathrm{mmHg}$ 芷示す加ら, 真空 中では蒸発して, 冷所付着することとなる。吃に， $\mathrm{Ca}_{3} \mathrm{WO}_{6}$ が分解する約 $1,100^{\circ} \sim 1,300^{\circ} \mathrm{C}$ の間虽時間, 真空度ともに適当们調節すれば金属カルシウム活ほとん ぞ完全に反応柔からとり除くことができるてととなる訳 である.

$\mathrm{CaWO}_{4}$ と炭素との反応は, 上記の要素的な順に起こ るとは限らす, 実際には, 昇温時間, 保持温度, 真空 度，炉の構造などで重複することが考光られる。これは 固相反応に特有なとととして瑟めざるを得ない。

\section{4. 結言}

$\mathrm{CaWO}_{4}$ と炭素とを真空中で加熱反応させて WC を製
造するさい，反応中間温度で垫める未知物質を確認する ため，若干の奏験を行なった結果，乙のものが $\mathrm{Ca}_{3} \mathrm{WO}_{\mathfrak{6}}$ 亿相当するととを諰めた。

これれよって，反応機構を考察し，中間で生ずる $\mathrm{Ca}_{3} \mathrm{WO}_{6}$ 方分解して金属カルシウムおよびタングステン 在生成し，金属カルシウムは蒸気圧が大であるため真空 焒内の泠処に蒸着し，タングステンは最終的に WC と なり，しかも WC 中には金属カルシウムをはとんど含 まないようになることを知った。

終わりに，こ指導を賜はった東京工業大学久保輝一郎 教授に深謝すると共に，実験に協力された三菱金属鉱業 新潟工場の明石忠雄, 小野喬雄, 三上山治の各技師に記 して謝意を表す。

(昭 $36-11-38$ 受理)

\section{文献}

1）堀口米次郎，的場敏夫，石丸安彦，本誌，29，843(1961)，

\title{
析出反応時の電気化学的挙動による金属の分類*
}

\section{The Classification of Metals from Electrochemical \\ Behavior in the Deposition}

\author{
三 根 剛 四 郎** \\ Takeshiro MINE
}

\section{1. 緒言}

オッシログラフィック・ステップ・ポーラライザ (O. S.P.) はすでに報告〉したよう汇電極現象の研究のため に製作した装置であって，図10ように，任意の電位か ら出発して，電解電流として 1 段の間は一定で階段状に 増加し，かつ1段でとにゼ口までしゃ断される電流を電 解ソウに与え，その間の電極電位の変化を陰極線オッシ ログラフによって蕉測，記録するものである．その奏際 の測定例は先に報告 ${ }^{13}$ したが，今回は金属カソード上

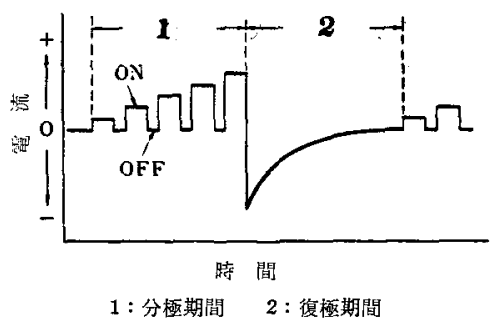

屌 1 O.S.P.によって電解ソウに与えられる電流の略図

* O.S.P.による電極現象の研究（第 1 報） Studies on Electrode Phenomina by O.S.P. (Part 1) 日本化学会第 13 年会昭和 35 年 4 月に講演

** 九州大学工学部応用化学教室（福岡県福周市箱䗁町）
へその金属の単純壏水溶液からの析出についてかなり広 範囲に測定し，その特性壳各金属について比較分類した 結果を報告する。

金属表面への金属の電解析出の現象，あるいは広く一 般に水溶液中の金属の電気化学的挙動については種々の 研究がなされてきたがその最も重要な手がかりの一つは 分極曲線あるいはその時間的変化である。

從来までのこの種の研究の多くは電解中の定常的な状 態を取り扱ったものであったが，最近電極反応論の立場 から，交流あるいはパルス的な電流または電圧を加えて 電極の交流インピーダンス，周波数応答あるいは電压， 電流の過渡的変化を測定して，論しられるようになっ た2)，乙れら非定常法では多くの場合平衡あるい柱定 值から大体 $5 \mathrm{mV}$ 以内の変動を取り扱引もので，実験装 置や陚料についてかなり㟶密な注意を必要とする。

これに対して O.S.P. は種々の電流に対する電極電位 の定常値と過渡的な変化とを一時に知るととができるも ので，現在の装置ではその感度から上の非定常法のよう な精密な実験仗できないけ扎ども，実際的な条件下でか なり広い範团の変化を直接観泪できるという点で独自の 機能を発揮する。 


\section{2. 実 験 方 法}

\section{1 電 解 液}

実験て当たっては濃度分極をできるだけ小さくするよ う注意した，濃度差による分極の大きさは，液を強くか きまぜた場合， $1 N$ 溶液中電流密度 $120 \mathrm{~mA} / \mathrm{cm}^{2}$ で 3 $\mathrm{mV}^{3}$ 程度となり，本実験では無視できる，そのため電 解滩の濃度はすべて $1 N$ とした。

\section{2 電解ソウおよび電極}

電極法測定電極, 分極用䋠助電極, 電 位測定用照合電極 0 3 者少構成され る・すなわち，測定 電極をカソードとし て補助電極との間に 分掼電流を流し，そ のひの測定電極と 照合電極との間の電 位差を測定する。測 表 1 実験に用いた電解液

\begin{tabular}{|c|c|c|c|}
\hline 金 属 & 篇 & 解 & 液 \\
\hline $\mathrm{Hg}$ & \multirow{2}{*}{\multicolumn{3}{|c|}{$\begin{array}{l}1 \mathrm{~N} \mathrm{Hg} 2\left(\mathrm{NO}_{3}\right)_{2}, 0.42 N \mathrm{HNO}_{3} \\
1 \mathrm{~N} \mathrm{SnCl}{ }_{2}, 1 N \mathrm{HCl}\end{array}$}} \\
\hline Sn & & & \\
\hline $\mathbf{P b}$ & \multicolumn{3}{|c|}{$1 \mathrm{~N} \mathrm{~Pb}\left(\mathrm{NO}_{3}\right)_{2}, 0.01 \mathrm{~N} \mathrm{HNO}_{3}$} \\
\hline $\mathrm{Ag}$ & \multicolumn{3}{|c|}{$1 \mathrm{~N} \mathrm{AgNO}, 0.01 \mathrm{~N} \mathrm{HNO}_{3}$} \\
\hline $\mathrm{Zn}$ & \multicolumn{3}{|c|}{$1 \mathrm{~N} \mathrm{ZnSO}_{4}$} \\
\hline $\mathrm{Cd}$ & \multicolumn{3}{|c|}{$1 \mathrm{~N} \mathrm{CdSO}_{4}$} \\
\hline $\mathrm{Cu}$ & \multicolumn{3}{|c|}{ 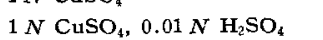 } \\
\hline $\mathrm{Bi}$ & \multicolumn{3}{|c|}{$1 \mathrm{~N} \mathrm{Bi(}\left(\mathrm{NO}_{3}\right)_{3}, 2.5 \mathrm{~N} \mathrm{HNO}_{3}$} \\
\hline $\mathrm{Sb}$ & \multicolumn{3}{|c|}{$1 N \mathrm{SbCl}_{3}, 2.6 \mathrm{~N} \mathrm{HCl}$} \\
\hline $\mathrm{Fe}$ & \multicolumn{3}{|c|}{$1 \mathrm{~N} \mathrm{FeSO}, 0.001 \mathrm{~N} \mathrm{H}_{2} \mathrm{SO}_{4}$} \\
\hline $\mathrm{Ni}$ & \multicolumn{3}{|c|}{$1 \mathrm{~N} \mathrm{NiSO}_{4}$} \\
\hline
\end{tabular}
定電極として多くの場合，回転白金電極を用いた．先端

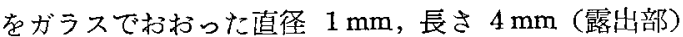
の白金線を直径 $8 \mathrm{~mm}$ のガラス管の側面に封じ込んだも ので，その上に測定する金属を厚さ $0.2 \sim 0.3$ ミロロ 程度（素地金属の結晶組織の影響が大体消失するとみら

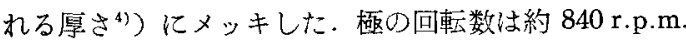
とした.

照合電極は測定電極の回転軸の回りを囲んだ環状の白 金リボンに測定電極と同様に，その金属をメッキしたも の，あるい棒状の同種金属を用いた，補助電極として は照合電極のさらに外側を国んだ同種金属，またはその 金属をメッキした白金りボンを用いた。

$\mathrm{Bi}, \mathrm{Sb}$ の測定では，適当なメッキ没がないので，そ の金属の小片を測定電極とし，補助電極および照合電極 にはその金属を融解して棒状に流したものを用いた。そ して別にかるまぜ棒を設けた。

また $\mathrm{Hg}$ の場合は測定電極として，ちようか水銀電 極"゙ならって金メッキした白金線上に $\mathrm{Hg}$ 付偖させ たもの，補助電極，照合電㮒としては精製 $\mathrm{Hg}$ 若用いた。

電解りウは $25^{\circ} \mathrm{C}$ 亿保ち，水素または窒素を電解液中 に吹き込んだ。

\section{3 測定装置}

先に報告》したO.S.P. 亿娰して実験上の種々の要 求に忘じえるように（たとえば，出力電流に対する電解 ソウの端子電压の影響の軽減および波形の改善，分極期 間および ON, OFF の時閻の可変，とり返しばかりで なく 1 回だけの分極をもなしうるこよなど）改良を加光 たもの莲网いた。

\section{3. 電気二重層の影亚}

O.S.P.による実験では，階段状電流の1段でとに $\mathrm{ON}, \mathrm{OFF}$ をくり返し，そのたびに電極界面の電気二重 熼の容量に対して充放電電流が流れるから，それに対す る考慮が必要となる。

電気二重層の容量 $C_{1}$ は一般に電極反応のインピーダ ンス $Z$ と並列として表示できる ${ }^{6)} . C_{1}, Z$ の值は電極の 種類, 極の電位その他の条件によって変化し, 電気的な 等価回路で正確に表わすことは困難であるが，電位の微 小変化の範囲内では一定值とみるととができる，その場 合に $Z$ の表示として，両端の電位差 $E$ は抵抗分 $R_{\mathrm{I}}$ (電圧は電流に比例.たとえば放電過程にお污る活性化 分極は電位変化の小さい範囲内では近似的にこのように 置きうる）と容量成分 $C_{2}$ （電圧は電流の積分に比例. 近似的には濃度分極その他電極表面の構造の変化など物 質移動に関する項）とにおける電压の和であり，かつ直 流を通過させるという意味で， $C_{1}$ と組み合わせて便宜

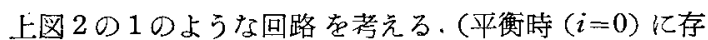
在する電極界面の電位差は考慮に関係しないので省略す る）ここで実祭の電極反応において時定数 $\tau_{1}=C_{1} R_{1}$ と $\tau_{2}=C_{2} R_{2}$ との大きさを比較すると, 反応機構によって も異なるが，通常の電気化学反応においては多くの場合

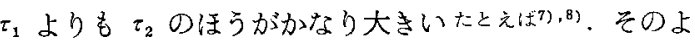
うな場合には，電流印加後短時間内の急激な電位変化に 対しては図 201 は 2 のうに,また長時間後の緩慢な 電位変化に対しては 3 のように考えることができる。し たがって図 2 の 2 から $(d E / d t)_{t=0}=i / C_{1}$ なる，よく知 られた関係が兊られ，これとよって電流印加直後の時間 的変化すなわち build up curve の最初の傾敍加らその ときの二重層の容量 $C_{1}$ を知ることができる．このよ うにして測定された平滑固体電極における二重層の容量 として通常 $20 \sim 100 \mu \mathrm{F} / \mathrm{cm}^{2}$ 程度の值か報告されてい $3^{73,8), 9)}$
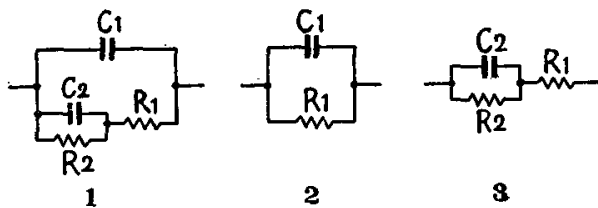

図 2 電気二重層の影響

次に本報て取り报うような，電流しゃ断後ある程度時 間が経過した後における二重層の影響について考光る。 その場合に図 203 が適用できるならば二重層の影響は 無視できるわけであるが，実際にどれぐらいの範間でそ のような考光方が適用できるかを見積ると次のようにな る.

種々の金属析出反応に対する時定数 $\tau_{1}, \tau_{2}$ は発表され ていないが，二重層の容量 $C_{1}$ としては上記のような例 
がある．また電流印加後の定常状態における分極の大き さは種々報じられているから，それから図2の1にお ける $R_{1}+R_{2}$ の值が算出できる，そうすると， $\tau_{1}=C_{1} R_{1}$ $\left\langle C_{1}\left(R_{1}+R_{2}\right)\right.$ だ加ら, 電流し 断後 $n C_{1}\left(R_{1}+R_{2}\right)>$ $n \tau_{1} \sec の$ 二重層の放電電流による分極電圧の值は，し 中断直後の值（それはしゃ断直前の分極電圧より大きく はない) $\left\{R_{1} /\left(R_{1}+R_{2}\right)\right\} \exp \left\{-n\left(R_{1}+R_{2}\right) / R_{1}\right\}$ 倍（乙 れは $\exp (-n)$ 倍よりる小さい)となる。すなわち二重 涩の寄与による分極電压仙 $n=5$ において電流し中断㨁 後の值の $e^{-5}, 0.66 \%$ 以下となる。また，電流通過時の 定常值における分極抵抗 $R_{1}+R_{2}$ が大きい場合には， $R_{1}$ と $R_{2}$ とを分離できない限り，電流しゃ断後，二重層に 対して考虑しなければならない範囲（h）が増大する.

その範囲を実例について計算してみると，本報て実験 した金属の中で，分極の大きさが中位の Cuについての 值は， $\left.C_{1}=78 \mu \mathrm{F} / \mathrm{cm}^{2}{ }^{8}\right)$ ，また $R_{1}+R_{2}$ の值として分極 $50 \mathrm{mV}$ 亿対する本実験の值から $7 \Omega \cdot \mathrm{cm}^{2}$ を用いると， $C_{1}\left(R_{1}+R_{2}\right) \fallingdotseq 0.55 \mathrm{~m}-\mathrm{sec}, 5 C_{1}\left(R_{1}+R_{2}\right) \fallingdotseq 3 \mathrm{~m}-\mathrm{sec}$ と なって，その時間以後は二重風の寄与による電圧は実験 の範囲内では最大（電流通過時の分極 $400 \mathrm{mV}$ に対し） $3 \mathrm{mV}$ 以下で，実験の精度から無視される程度である。 したがって本実験の結果について論じる範围内では二重 風の影望を考无る必要がないことがわかる，また，電流 し中断後，上のような特間が経過してからもなおかなり

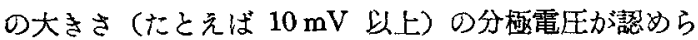
れる場合には，その原因は二重冨以外の，たとえば電極
の表面状態などにあると考えられる，実験した金属の大 部分ては $\left(C_{1}\right.$ を $100 \mu \mathrm{F} / \mathrm{cm}^{2}$ 以下とみれば $)$ 上と同様 であるが，分極抵抗の大きい $\mathrm{Sb}, \mathrm{Ni}$ では二重層に対す る顧虑がある程度必要となる。との点についてはその項 で触れる。

\section{4. 実 験 結 果}

代表的な数例について図によつて説明し，ほかは数值 だけを表 2 としてあげた。

(i) Sn 分極曲線の全体の形を図 3 に，その一部分 の時間軸桩大図を図4 亿あげる．分極図形はごく短い過 渡期を除いては，加えた分極電流の波形にほとんど等し く，その点で抵抗に近い挙動を示す.図4 から見ると， 電流しゃ断後 $0.001 \mathrm{sec}$ 以内に平衡電位* そ復㴆してい る. また図 3 から分極 $50 \mathrm{mV}$ 亿対する電流密度 $i \mathrm{~mA} /$ $\mathrm{cm}^{2}$ 加分極等価抵抗 $\left(50 / i \Omega \cdot \mathrm{cm}^{2}\right)$ を求めると，約 $0.8 \Omega$ となる。

$\mathrm{Hg}, \mathrm{Pb}$ および $\mathrm{Ag}$ もほぼてれと同様であった。

(ii) $\mathrm{Cu}$ 条件を変えて測定した2種類の結果を図5, 図6亿あげる。乙れらはSnなどと比較して，ON, OFF の各段でとに電位の過渡的な変化が目立ち，定常的な電 位に達するのにかなりの時間を要することか認められ る.図 5 のように OFF の時間が短い（約 $0.005 \mathrm{sec}$ ) 場合には，その間に平衡電位まで復州しない。

Zn および Cd（図7）は，Cuほど顕著ではないが， やはり同様の傾向を示した。

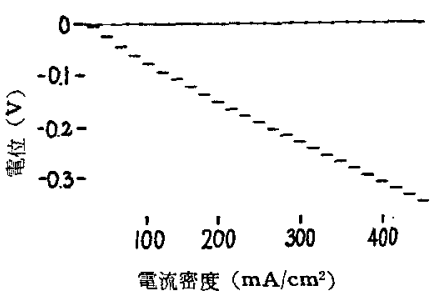

図3 $1 \mathrm{~N} \mathrm{SnCl}_{2}, 1 \mathrm{~N} \mathrm{HCl}$ 中 $\mathrm{Sn}$ カソードの分極曲線 時間 $(\mathrm{sec})$

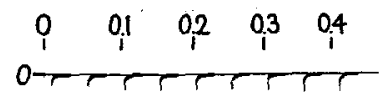

$>-0.1-$

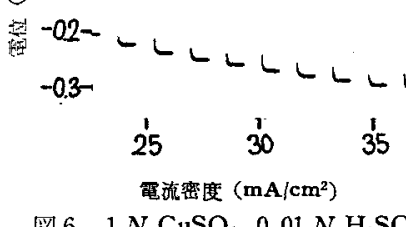

図61 $\mathrm{N} \mathrm{CuSO}$, $0.01 \mathrm{~N} \mathrm{H}_{2} \mathrm{SO}$, 中 $\mathrm{Cu}$ カソードの分極曲線 (ii)

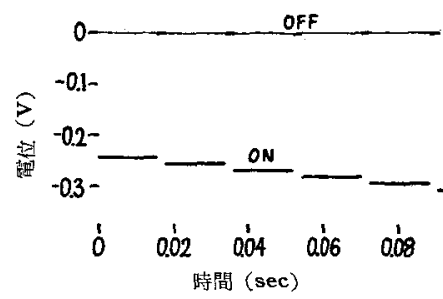

図 4 図 3 の部分拡大図

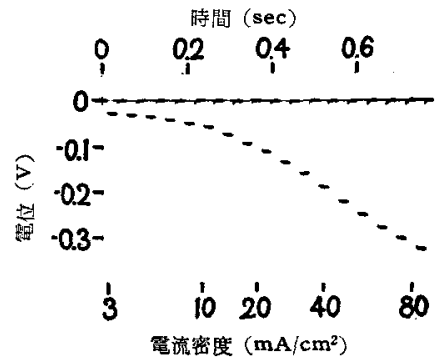

図 $71 N \mathrm{CdSO}$ \& 中 $\mathrm{Cd}$ カソート の分極曲線

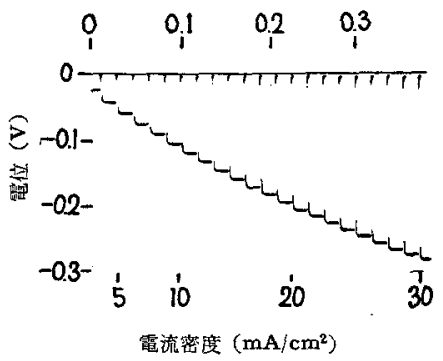

图 $51 \mathrm{~N} \mathrm{CuSO}_{4}, 0.01 \mathrm{~N} \mathrm{H}_{2} \mathrm{SO}_{4}$ 中 $\mathrm{Cu}$ カソードの分極曲線 (i)

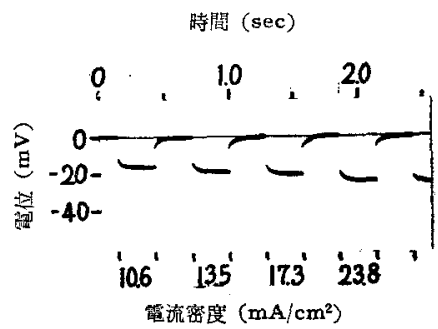

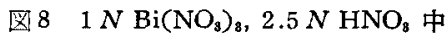
$\mathrm{Bi}$ カソードの分極曲線

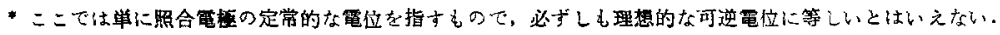




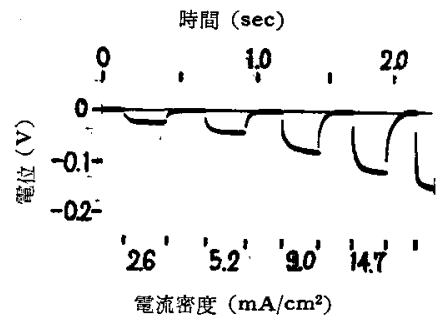

図 $91 \mathrm{~N} \mathrm{FeSO}_{4}, 0.001 \mathrm{~N} \mathrm{H}_{2} \mathrm{SO}_{4}$ 中

$\mathrm{Fe}$ カソードの分極曲線

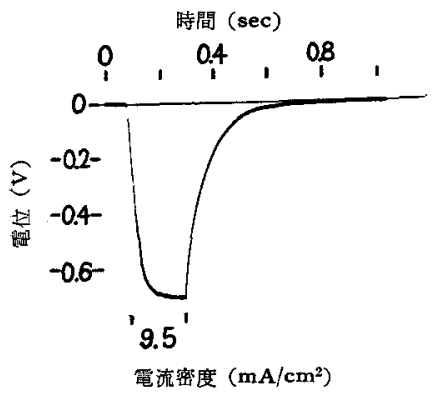

図 $1010 \mathrm{~N} \mathrm{NiSO}$ ，中 $\mathrm{Ni}$ カソードの分極曲線

(iii) $\mathrm{Bi}, \mathrm{Sb}$ および $\mathrm{Fe}, \mathrm{Ni}, \mathrm{Bi}, \mathrm{Fe}$ および $\mathrm{Ni}$ の例 を図 8,9,10 にあげるが，てれらは電流 ON, OFF のさ いの過渡的な電位変化が著しく，かつ定労値に達するの に長時間を要する．また $\mathrm{Sb}, \mathrm{Ni}$ は他の金属に比べて分 極が特に大きかった：とのように分極が大きい場合には 電流断続にさいしての過渡現象に対しては電極界面の電 気二重層の影響が無視できないが，その影響する時間を 前節のようにして 概算すると， $\mathrm{Sb}$ で $0.04 \mathrm{sec}, \mathrm{Ni}$ で $0.2 \mathrm{sec}$ 程度となり, 電流し中断後それ以上の時間, す なわち二重層以外の原因による分極力残っていることが 認められた。また二重層の容量を計算すると， $\mathrm{Ni}$ で電 流密度 $1.4 \mathrm{~mA} / \mathrm{cm}^{2}$ の場合について，くり返し掃引によ って時閪軸を拡大し, 電位対時間の傾斜から得た值は約 $95 \mu \mathrm{F} / \mathrm{cm}^{2}$ となった。

各金属についての結果を表 2 に総括しだ．表におい て分極抵抗はすべて分極 $50 \mathrm{mV}$ に対する值であるが， ただ $\mathrm{Bi} は 25 \mathrm{mV}, \mathrm{Ni}$ は $100 \mathrm{mV}$ に対する值である。 もちろんてれらの俻には，液抵抗による電位降下も含ま
れ，また計算に用いた分極の大きさによってそれぞれ異 なるふらに変化するので理論的な意味は薄いが，実際的 な立場から各金属の分極を比較する一つの目安にはなり えよう。

また，分極電流しゃ断後，その金属極が平衡電位 \pm 5 $\mathrm{mV}$ に達するまでの大体の時間を復㷌時間として，しゃ 断前の分極電流密度と共に列記した。これらは実験結果 の中から.し中断後の電位に過渡的な变化が見られ $(\mathrm{Hg}$ では実験の範国内でははとんど琶められなかったがかが つ1段の OFF 時間内にほぼ平衡電位まで復帰するよう な電流密度を選んだので，その電流密度はかなりまちま ちになった。さらに復㴆時間はあまりはっきりした值を 定めがたく，また ON の電流密度や時間などによって も変動するのでしれまた緟密な意味を持ったものではな いが，各金属のおよその傾向は知るととがでるる。

\section{5. 考察}

以上の実験結果を通観すると，実験した各種全属は， それが同種金属上に析出するさいの電位的挙動から炊の 3 種に大別される.すなわち，抵抗とはとんど同じよう に，かなり高い電流密度で分極しても，電流をしゃ断す れば分極は残らず，短時間の内に安定な平衡電位に落ち 着くもの [前節分類 (i)] と，逆に小さな電流密度に対 しても分極の影響が電流しゃ断後ながく残り，安定な平 衡電位を得がたいもの[分類 (iii)] とがあり，また両者 の中問程度の性質を示すもの[分類（ii)] あることが 認められた。

表 2 を見ると，Bi を除けば，分極等価抵抗も復㷌時 間とは注同已傾向走示し，だいたい分類 (i)，(ii)，(iii) の順に増加しており，また同族元素 $\mathrm{Bi}$ と $\mathrm{Sb}$ とでは $\mathrm{Sb}$ が, $\mathrm{Fe}$ と $\mathrm{Ni}$ とでは $\mathrm{Ni}$ が分極抵抗，復㷌時間と もに大きく，平衡電位がえがたいことを示している。

カソードにおける金属析出過程は, 種々発表されてい

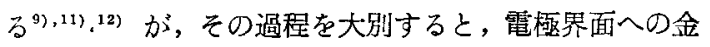
属イオンの液中の移動, 界面の通過 (電荷交換), 電極 表面における結晶格子への組み込み，の3段階を考える ことができる。これらの過程のいずれかの段階の遅れが 表 2 金属析出反応における分極等価抵抗および復州時間

\begin{tabular}{|c|c|c|c|c|c|c|c|c|c|c|c|}
\hline 類 & \multicolumn{4}{|c|}{ (i) } & \multicolumn{3}{|c|}{ (ii) } & \multicolumn{4}{|c|}{ (iii) } \\
\hline 属 & $\mathbf{H}_{\mathbf{g}}$ & Sn & $\mathbf{P b}$ & $\mathrm{Ag}$ & $Z_{\mathbf{n}}$ & $\mathrm{Cd}$ & $\mathrm{Cu}$ & $\mathrm{Bi}$ & Sb & $\mathbf{F e}$ & $\mathrm{Ni}$ \\
\hline $\begin{array}{c}\text { 分㟳等価抵抗 } \\
\left(\Omega \cdot \mathbf{c m}^{2}\right)\end{array}$ & 0.25 & 0.8 & 1.3 & 1.3 & 4 & 6 & 7 & 1 & 70 & 8 & $>300$ \\
\hline 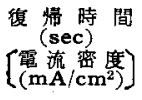 & $\begin{array}{r}<0.001 \\
{[100]}\end{array}$ & $\begin{array}{r}<0.001 \\
{[100]}\end{array}$ & $\begin{array}{r}<0.001 \\
\quad[100]\end{array}$ & $\begin{array}{r}<0.002 \\
{[40]}\end{array}$ & $\begin{array}{r}<0.01 \\
{[10]}\end{array}$ & $\begin{array}{r}<0.01 \\
\quad[10]\end{array}$ & $\begin{array}{r}<0.02 \\
{[30]}\end{array}$ & $\begin{array}{l}0.2 \\
\quad[17]\end{array}$ & $\begin{array}{c}0.7 \\
{[0.3]}\end{array}$ & $\begin{array}{c}0.1 \\
{[5.2]}\end{array}$ & $\begin{array}{c}0.5 \\
{[1.4]}\end{array}$ \\
\hline
\end{tabular}

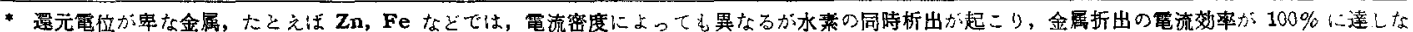

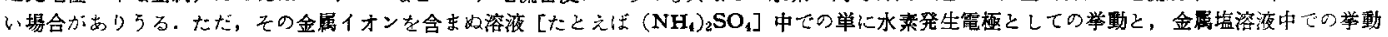
とを此較すると，電位の過渡的な变化において差異が見られる。こにに Feの場合に著しいが,これらの金属については，O.S.P.によって水素発

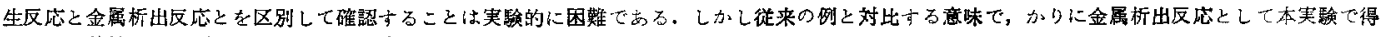
られた電位波形を分類すると，表战よび本文のようになる。 
分極（いわゆる過電在）の原因となるわけであるが，そ の中で溶液中のイオンの移動の影響は 2 亿述べたように あまり大きくない（本実験の結果でも，分類 (i) の金属 では電位の過渡的な変化が扸さい，他の金属イオンの移 動速度も大差ないとすれば，この影響は分類 (ii)，(iii) に执いても比較的小さいものと思われる).分類 (i) の金 属では残余の過程においても大きな障害がなく，金属イ オンは析出後ただちに平衡電位を示すような安定な結晶 構造に落着くものであり, (iii) ではその逆であると言 える.このうち電荷交換速度を示す数值として交換電流 があるが，すでに知られている ${ }^{13)}$ ように，概して（i） の金属では大きく，(ii)，(iii)となるにしたがって小さ くなっている.分極等価抵抗（正しくは液の抵抗を除い たもの）は電荷交換，結晶組み达みの画者の影響の和で あり，復㷌時間は（放電が終わった後の過程であるか ら）界面の電気二重層の影響が無視できる場合には，主 として放電以外の結晶組み达みの速度などを示すものと みるととができる. $\mathrm{Sb}, \mathrm{Ni}$ のように分極の大きいもの でも，前節に述べたように，二重層の影響と考えられる

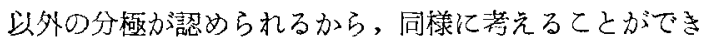
る. Ni の分極の大きい点について Conway ら ${ }^{12)}$ は析 出のさいの $\mathrm{Ni}^{2+}$ イオンの転移において $\mathrm{Ag}^{+}, \mathrm{Cu}^{2+}$ ぬ どに比べてはるか高い活性化エネルギーを要するとし ている。

これらの点についてはさらに精細な触討が必要である が、このようにO.S.P.によって得られた金属の分極曲 線や，表 2 数㯰は，金属析出にさいしての挙動具体 的に示すものとして実祭的な意義があるものと考えられ \%.

各種金属の電気化学的挙動による分類は種々なされて いる. Fischer ${ }^{10}$ は, 低融点, 低渦電圧のもの $(\mathrm{Hg}, \mathrm{Bi}$, $\mathrm{Pb}, \mathrm{Cd}, \mathrm{Sn}, \mathrm{Tl})$, 加引り過電压を示すもの( $\mathrm{Zn}, \mathrm{Cu}$, $\mathrm{Ag}, \mathrm{Au}$ ), 高融点, 高過電生のもの ( Fe 族および $\mathrm{Pt}$ 族）上した。

また Piontelli ${ }^{14)}$ は，金属がその金属イオンを含む溶 液中にあって外部電流も局部電流も存在しないときにそ の金属がこる電位 $E_{M}$ の定常性と再現性といら点から， 次のような3つの群に分類した。

第1のグループでは $E_{M}$ の值は一定で再現性があり， また電極の履歴の影響が比較的少なく，一般にその平衡 電位とほとんど一致する。この種の金属老“normal metals”之呼び， $\mathrm{Pb}, \mathrm{Tl}, \mathrm{Sn}, \mathrm{Cd}, \mathrm{Hg}$ などがその例で ある。

第 2 の゙ループの金属は “intermediate metals”之呼 ばれるが，その挙動は電流りないときは実際上 normal である. normal metals との区別は外部電流を流した場 合の電気化学的挙動に現わ机る。 $\mathrm{Zn}, \mathrm{Cu}, \mathrm{Ag}, \mathrm{Bi}, \mathrm{Sb}$ るどかとれに属古る。
第 3 のダループは “inert metals”之烀ばれて遷移元 素 $\mathrm{Fe}, \mathrm{Co}, \mathrm{Ni}$ な゙がその典型的な例であるが，てれら， では種々の環境条件の影響が大きく，不測の原因による 変動もあって，実際に示す $\mathrm{EM}$ は一定しにくく，理想 的な值との差が大きい。

Piontelli はこの研究を，いわゆる直接法で電解ソウ に直流またはパルス電流を流して $E_{M}$ の值を测定または 記録することによって行なったが，O.S.P. を用いた本 実験の結果による分類 (i), (ii)，(iii) はそれぞれ Piontelli $\odot$ normal, intermediate, inert metals $と \mathrm{Ag}$, $\mathrm{Cd}, \mathrm{Bi}, \mathrm{Sb}$ を除いては一致し，また Fischer の分類と もだいたい一致している.Piontelli はまた， $\mathrm{Ag}, \mathrm{Cu}$. An のシリーズでは $\mathrm{Ag}$ が最も normal で $\mathrm{Cu}, \mathrm{Au} の$ 順に inert そなり， $\mathrm{Bi}, \mathrm{Sb}$, As のシリーズでも同様に この順に inert 性が増すと述心゙ているが，これも傾问的 には本実験の結果と一致している。

\section{6. 総 括}

金属カソード上に同種金属がその単純塩 $1 N$ 溶液か ら析出するさいの電気化学的挙動支 O.S.P. によって測: 定し，その結果から各金属を次の3 種に分類した。

(i) 電解電流通過時の分極が比較的小さく，電流し や断後, 短時間内江平衡電位に復帰するもの: $\mathrm{Hg}, \mathrm{Sn}$, $\mathrm{Pb}, \mathrm{Ag}$.

(ii) 分極，復㴆時間之もやや大きいもの: $\mathrm{Zn}, \mathrm{Cd}$, $\mathrm{Cu}$.

(iii) 概して分極が大きく，過渡的な電位な示す時間 が長くて平衡電位に復浔するのに長時間を要するもの： $\mathrm{Bi}, \mathrm{Sb}, \mathrm{Fe}, \mathrm{Ni}$.

この分類は過電圧の大きさあるいは平衡電位の安定性 を基準として Fischer あるいは Piontelli が行なった分 類とほぼ一致し, O.S.P. 亿よって各金属の析出にさい しての動的抢よび静的特性がよくはあくされるととを示 Uた.

本研究に当っては当学部坂井渡教授, 清山唯郎教授に 終始懇切なご指導を賜わった・また電気的方面について は電子工学教室入江富士男教授, 電気工学教室富安隆一 氏にご教示ご検討をいただいたとこに梁く感謝の意を 表する・

（昭 37-1-5 受理）

\section{文献}

1)三柫制四郎，本就，28，106 (1960).

2）多数の報告があるがた之えば D.C. Graham，J. Electrochem, Soc，99，370 C (1952)，水野滋，市䋦信，本梳，28，318 (1960), T. Bersins, P. Delahay, Z. Elektrochem. 59, 792 (1955). など.

3) G. Kortiim, J. O'M. Bockris, "Textbook of Electrochemistry" p. 405 (1951). Elsevier Publishing Co., London.

4) G.I. Finch, H. Wilman, L. Yang, Discuss. Faraday Soc., I. 144 (1947).

5) 日本分析化学会, “新分㟁化学請座 2, 微量電気分析法” p.9 (1960). 
共立出版.

6) P. Delahay "New Instrumental Methods in Electrochemistry" p. 146 (1954), Interscience Publishers, Inc., New York.

7) J.J. McMullen, N. Hackerman, J. Electrochem. Soc., 106, 341 (1959).

8) E. Mattson, J. O'M. Bockris, Trans. Faraday Soc., 55, 1586 (1959).

9) H. Fischer, "Elektrolytische Abscheidung und Elektrokristallisation von Metallen" p. 119 (1954), SpringerVerlag, Berlin.
10) Ibid. p. 158.

11) H. Gerischer, Z. Elektrochem. 62, 256 (1958).

12) B.E. Conway, J. O'M. Bockris, Proc. Roy. Soc,, A 248, 394 (1958).

13) J. O'M. Bockris, "Modern Aspects of Electrochemistry" p. 217 (1954), Butterworths Scientific Publications, London，田中信行，玉惑佮太，“現代化学，電極反応”p. 35 (1956)， 岩波畫店.

14) R. Piontelli, Proc. 2nd Meeting (Milan 1950) CITCE, p. 163 (1951) Milan, Z. Elektrochem. 55, 128 (1951), Corro. sion, 9, 115 (1953).

\section{解 コウ 電 池 の 起 電 力*}

\section{Electromotive Force of Sodium Amalgam Cell}

\section{1. 緒言}

水銀法食塩電解で，陰極に生成するナトリウムアマル ガムを解コウし，水素とカセイソーダを製造する反灾は 元来電池反応であり，陰極材質たと光ば黒鉛と陽極アマ ルガムを短絡させて反応を進めている。この電池におい て，陰極乙陽極を短絡することなく，導線で外部的に連 結すれば，解コウエネルギーを電気エネルギーとして利 用するとこができる．解コウ電池の利用は食塩電解工業 の電力節娍対策として虽望されるが，これには電池の起 電力, 分極, 出力電圧などの特性を知らなければならな い. 解コウ電池の起電力は重山の著書”に一部述へられ ている程度で, 徒来ほとんど郝告がなかった。筆者らは 解コウ電池心研究において，まずその起電力党，いまま で知られている電気化学の測定値を利用して理諭計算に より求めた。つついて, 種々の温度のもとで, 力セイン 一ダ溶液に対するナトリウムアマルガムの平衡電位打よ び水素ガスの平衡電位を測定した．この両者から起電力 を実測做として求め，その特性を解析し，解コウ電池の 工業的利用について基礎資料を与光た。

\section{2. 理論計算による起電力}

解コウ電池の起電力は次の反応式に基づいて表わされ 万.

$\mathrm{Na}$ (in amalgam) $+\mathrm{H}_{2} \mathrm{O}=\mathrm{NaOH}+1 / 2 \mathrm{H}_{2}(1 \mathrm{~atm})$

*解コウ電池に関与万基礎研究（第 1 韩） Fundamental Studies on Sodium Amalgam Cell (Part 1) 電気化学協会第 24 回 大会（昭和 32 年 4 月）以一部発表

**味の素怢式会社川崎工場（神奈川県川崎南鉿木町）

*** 京都大学工学部工業化学教室 (京都市宥京区吉田)
青木 斌**，吉 沢四郎*** Kiyoshi Aokr, Shiro Yoshizawa 岡田辰 三***, 長池浄 見** Shinzo Okada, Kiyomi NagaIke

$$
E=E_{0}+R T / F \ln a_{\mathrm{Na}} a_{\mathrm{H}_{2} \mathrm{O}} / a_{\mathrm{NaOH}}
$$

ただし， $E_{0}$ : 標準起電力 $a_{\mathrm{Na}}$ ：アマルガム中のナ

トリウムの活量 $a_{\mathrm{NaOH}}$ : 水浴液中のカセイソーダ の活量 $a_{\mathrm{H}_{2} \mathrm{O}}$ ：カセイソーダ溶液中ゆ水の活量 $E_{0}$ 㹥金属ナトリウムの活量を 1 とするとき，純水と反 応して活量 1 の力セイソーダ水溶液と 1 気生の水素ガス を生成する埸合の起電力であり，次の標準単極電位差か ら求められる。

$$
\begin{aligned}
\mathrm{Na}(s) & \rightleftharpoons \mathrm{Na}^{+}+e \quad E_{298}^{0}=2.7125 \mathrm{~V}^{2)} \quad(3) \\
\mathrm{H}_{2} \mathrm{O}(l)+e & \rightleftharpoons \mathrm{OH}^{-}+1 / 2 \mathrm{H}_{2} E_{298}^{0}=-0.8280 \mathrm{~V}^{3)}(4) \\
E_{0} & =1.8845 \mathrm{~V} \quad(5)
\end{aligned}
$$

アマルガム中のナトリウムの活量については, 吉沢ら ${ }^{4)}$,

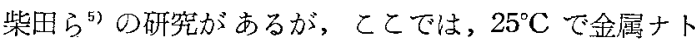
リウムと濃度 $0.206 \%$ のトリウムアマルガムの間の電 位差を測定した Lewis $ら^{6)}$ の結果，および同温度で濃 度 $0.551 \%$ から $0.0197 \%$ までのナトリウムアマルガム 間の電位差を測定した Richard ら”の結果を利用して， ナトリウムの活量に関する標準起電力の補正項を計算し た. 水溶液中のカセインーダの活量は Stokes の平均活 量係数測定值 ${ }^{8)}$ より求めた。 カセインーダ溶液中の水の 活量は同水溶液の水蒸気压を Perry ${ }^{9}$ のハンドブックの 值から内そうして求め, 純水の水蒸気压と口比から兑 た.これら活量を(2) 式の標準起電力補正項に代入し， $25^{\circ} \mathrm{C}$ における解コウ電池起電力の計算值として表 $1 の$ 値を得た。

\section{3. 実測による起電力}

実測による解コウ電池の起電力はカセイソーダ水溶液 におけるナトリウムアマルガムおよび水素ガスの平衡電 